\title{
Tat-thioredoxin 1 reduces inflammation by inhibiting pro-inflammatory cytokines and modulating MAPK signaling
}

\author{
EUN JI YEO ${ }^{1 *}$, MIN JEA SHIN $^{1 *}$, HYEON JI YEO ${ }^{1}$, YEON JOO CHOI ${ }^{1}$, EUN JEONG SOHN ${ }^{1}$, LEE RE LEE ${ }^{1}$, \\ HYUN JUNG KWON ${ }^{2}$, HYUN JU CHA ${ }^{1}$, SUNG HO LEE ${ }^{1,3}$, SUNGHOU LEE ${ }^{4}$, YEON HEE YU ${ }^{5}$, DUK-SOO KIM ${ }^{5}$, \\ DAE WON KIM ${ }^{2}$, JINSEU PARK ${ }^{1}$, KYU HYUNG HAN ${ }^{1}$, WON SIK EUM ${ }^{1}$ and SOO YOUNG CHOI ${ }^{1}$ \\ ${ }^{1}$ Department of Biomedical Science and Research Institute of Bioscience and Biotechnology, Hallym University, \\ Chuncheon, Gangwon 24252; ${ }^{2}$ Department of Biochemistry and Molecular Biology, Research Institute of Oral Sciences, \\ College of Dentistry, Gangneung-Wonju National University, Gangneung, Gangwon 25457; ${ }^{3}$ Genesen Inc., \\ Seoul 06181; ${ }^{4}$ Department of Green Chemical Engineering, Sangmyung University, Cheonan, \\ Chungcheongnam 31066; ${ }^{5}$ Department of Anatomy and BK21 FOUR Project, College of Medicine, \\ Soonchunhyang University, Cheonan, Chungcheongnam 31538, Republic of Korea
}

Received December 22, 2020; Accepted April 29, 2021

DOI: $10.3892 / \mathrm{etm} .2021 .10831$

\begin{abstract}
Thioredoxin 1 ( $\operatorname{Trx} 1)$ serves a central role in redox homeostasis. It is involved in numerous other processes, including oxidative stress and apoptosis. However, to the best of our knowledge, the role of Trx1 in inflammation remains to be explored. The present study investigated the function and mechanism of cell permeable fused Tat-Trx 1 protein in macrophages and a mouse model. Transduction levels of Tat-Trx1 were determined via western blotting. Cellular distribution of transduced Tat-Trx1 was determined by fluorescence microscopy. 2',7'-Dichlorofluorescein diacetate and TUNEL staining were performed to determine the production of reactive oxygen species and DNA fragmentation. Protein and gene expression were measured by western blotting and reverse transcription-quantitative PCR (RT-qPCR), respectively. Effects of skin inflammation were determined using hematoxylin and eosin staining, changes in ear weight and ear thickness, and RT-qPCR in ear edema animal models. Transduced Tat-Trx1 inhibited lipopolysaccharide-induced cytotoxicity and activation of NF- $\kappa$ B, MAPK and Akt. Additionally, Tat-Trx1 markedly reduced the production of inducible nitric oxide synthase, cyclooxygenase- 2 , IL-1 $\beta$, IL- 6 and TNF- $\alpha$ in macrophages.
\end{abstract}

Correspondence to: Dr Soo Young Choi or Dr Won Sik Eum, Department of Biomedical Science and Research Institute of Bioscience and Biotechnology, Hallym University, 1 Hallymdaehak-gil, Chuncheon, Gangwon 24252, Republic of Korea

E-mail: sychoi@hallym.ac.kr

E-mail:wseum@hallym.ac.kr

*Contributed equally

Key words: Tat-thioredoxin 1, inflammation, MAPK, cytokines, protein therapy
In a 12-O-tetradecanoylphorbol-13-acetate-induced mouse model, Tat-Trx1 reduced inflammatory damage by inhibiting inflammatory mediator and cytokine production. Collectively, these results demonstrated that Tat-Trx1 could exert anti-inflammatory effects by inhibiting the production of pro-inflammatory mediators and cytokines and by modulating MAPK signaling. Therefore, Tat-Trx 1 may be a useful therapeutic agent for diseases induced by inflammatory damage.

\section{Introduction}

Inflammation is known to involve a series of physiological responses to various stimuli, including pathogen, chemical, and damaged cells of the host $(1,2)$. It plays a crucial role in various diseases including neuronal diseases (3-5). Endotoxin lipopolysaccharide (LPS) can initiate inflammatory responses. Once macrophages are stimulated and activated by LPS, they can produce pro-inflammatory mediators and cytokines including cyclooxygenase-2 (COX-2), inducible nitric oxide synthase (iNOS), interleukin-1beta (IL-1 $\beta$ ), IL-6, tumor necrosis factor- $\alpha$ (TNF- $\alpha$ ), and reactive oxygen species (ROS) (6-12). ROS also play a critical rule in the inflammatory diseases. High levels of ROS can induce macrophage activation, eventually leading to the production of cytokines and the activation of inflammation signaling pathways $(11,12)$.

Mitogen activated protein kinases (MAPKs) and nuclear factor-kappaB $(\mathrm{NF}-\kappa \mathrm{B})$ signaling pathways are involved in LPS-induced inflammation $(1,13)$. NF- $\kappa$ B plays a central role in inflammatory response through expression of inflammatory factors $(14,15)$. In addition, MAPK family members activated by LPS are associated with the production of inflammatory factors $(16,17)$. Thus, inhibiting MAPK and NF- $\kappa$ B activation might have potential as a therapeutic strategy to ameliorate inflammatory diseases.

Thioredoxin $1(\operatorname{Tr} x 1)$, a redox regulating protein, plays crucial roles in cell growth, cell protection against 
neurotoxicity, and inhibition of apoptosis $(18,19)$. Recently, Wu et al (20) have reported that Trx1 overexpression can suppress methamphetamine (METH)-induced inflammation and oxidative stress in mice spleen and suggested that Trx1 might be an important therapeutic target for METH-induced immune dysfunction. Chen et al (21) have shown that overexpression of Trx1 in transgenic mice can increase survival from sepsis by suppressing ER stress induced NF- $\mathrm{KB}$ inflammatory signaling, suggesting that $\operatorname{Trx} 1$ might be a potential drug target for treating sepsis. Although Trx1 plays beneficial roles in the immune system, the precise mechanism involved in the effect of Trx1 on inflammation remains unclear. In this study, we examined effects of Trx1 on inflammatory responses in macrophages and an animal model using cell permeable Tat-Trx1 fusion protein.

\section{Materials and methods}

Materials. We obtained LPS and TPA from Sigma-Aldrich. Antibodies were provided by Cell Signaling Technology. All other chemicals were used of high quality reagent grade.

Cell culture, protein treatment and western blotting. DMEM was used in the culture of Raw 264.7 cells as described previously $(22,23)$. Tat-Trx 1 protein was purified using a $\mathrm{Ni}^{2+}-\mathrm{NTA}$ and PD-10 column chromatography and removed endotoxins from purified protein as described previously (24). Briefly, this protein was treated with Detoxi-Gel ${ }^{\mathrm{TM}}$ (Pierce) according to manufacturer's instruction and the proteins $(<0.03 \mathrm{EU} / \mathrm{ml})$ were confirmed using a Limulus amoebocyte lysate assay (BioWhitaker).

For concentration- and time-dependent transduction of Tat-Trx1, Raw 264.7 cells were treated with different concentrations $(0.1-1 \mu \mathrm{M})$ of Tat-Trx 1 for $1 \mathrm{~h}$ or with time periods (15-60 min) of Tat-Trx1 $(1 \mu \mathrm{M})$. After transduction, the cells were further incubated and intracellular stability of Tat-Trx1 was determined by western blotting using an anti-histidine antibody. Western blotting was performed as described previously $(22,25)$.

Western blot analysis. Equal amounts of sample proteins were separated with $15 \%$ SDS-PAGE and transferred to a nitrocellulose membrane. The membrane was blocked with $5 \%$ nonfat dry milk in TBST buffer $(25 \mathrm{mM}$ Tris- $\mathrm{HCl}, 140 \mathrm{mM} \mathrm{NaCl}$, $0.1 \%$ Tween-20, $\mathrm{pH} 7.5$ ) for $1 \mathrm{~h}$. The membranes were immunoblotted with the indicated primary and HRP-conjugated secondary antibodies as recommended by the manufacturer. The protein bands were detected using enhanced chemiluminescent reagents (Amersham).

ROS staining. ROS staining was performed as described previously $(25,26)$. As the optimization period of the ROS production and DNA fragmentation by LPS in Raw 264.7 cells is different, the time of ROS staining and TUNEL staining are different, respectively. Therefore, we performed the staining of ROS and TUNEL at the optimal time by LPS. To determine the optimal ROS staining time, we performed ROS staining over various times, and we confirm that the optimal time is $3 \mathrm{~h}$ under this experimental condition (data not shown). Tat-Trx $1(1 \mu \mathrm{M})$ pre-treated for $1 \mathrm{~h}$ and LPS $(1 \mu \mathrm{g} / \mathrm{ml})$ exposed for $3 \mathrm{~h}$. Cells were then washed twice with PBS and stained with DCF-DA $(20 \mu \mathrm{M})$ for $30 \mathrm{~min}$. Fluorescent images were obtained by fluorescence microscopy (Nikon eclipse 80i) and the fluorescence intensity was detected with excitation at $485 \mathrm{~nm}$ and emission at $538 \mathrm{~nm}$ using a Fluoroskan ELISA plate reader (Labsystems Oy).

TUNEL staining. TUNEL staining was performed as described previously $(25,26)$. As the optimization period of the ROS production and DNA fragmentation by LPS in Raw 264.7 cells is different, the time of ROS staining and TUNEL staining are different, respectively. Therefore, we performed the staining of ROS and TUNEL at the optimal time by LPS. To determine the optimal TUNEL staining time, we performed TUENL staining over various times, and we confirm that the optimal time is $12 \mathrm{~h}$ under this experimental condition (data not shown). Tat-Trx $1(1 \mu \mathrm{M})$ pre-treated for $1 \mathrm{~h}$ and LPS $(1 \mu \mathrm{g} / \mathrm{ml})$ exposed for $12 \mathrm{~h}$. TUNEL staining was performed using a Cell Death Detection kit (Roche Applied Science, Basel, Switzerland). Fluorescent images were obtained by fluorescence microscope (Nikon eclipse 80i). Fluorescence intensity levels were measured using a Fluoroskan ELISA plate reader (Labsystems Oy) at $485 \mathrm{~nm}$ excitation and $538 \mathrm{~nm}$ emission.

Reverse transcription-quantitative PCR (RT-qPCR) analysis. Raw 264.7 cells $\left(10^{5}\right.$ cells/well) were grown overnight in 12-well plate and total RNA extracted using easy-BLUE according to the manufacturer's instructions (iNtRON). Also, mouse skin tissue $(50 \mathrm{mg})$ was used for total RNA extraction using TRIzol reagent (Life Technologies). The cDNA synthesis was performed using $2 \mu \mathrm{g}$ of total RNA with cDNA Reverse Transcription Kit (Omniscript ${ }^{\circledast}$ RT Kit) as per the manufacturer's instructions (Qiagen). The mRNA levels were quantified using a SYBR Premix Ex Kit (Bio-Rad) with a CFX Real time PCR Detection Systems (Bio-Rad). The relative gene expression levels were normalized to GAPDH and calculated using the 2- ${ }^{\Delta \Delta C q}$ method (27).

The primer sequences for PCR were as follows: COX-2 (sense: 5'-CCAGCACTTCACCCATCAGTT-3'; antisense: 5'-AAGGCGCAGTTTATGTTGTCTGT-3'), iNOS (sense: 5'-GGCTGCCAAGCTGAAATTGAAT-3'; antisense: 5'-CGTGATAGCGCTTCTGGCTCTT-3'), IL-1 $\beta$ (sense: 5'-TGTGTTTTCCTCCTTGCCTC-3'; antisense: 5'-TGCTGCCTAATGTCCCCTTG-3'), IL-6 (sense: 5'-AAGGAGTGGCTAAGGACCAAGAC-3'; antisense: 5'-AGTGAGGAATGTCCACAAACTGATA-3'), TNF- $\alpha$ (sense: 5'-CTTGTTGCCTCCTCTTTTGC TTA-3'; antisense: 5'-CTTTATTTCTCTCAATGACCCGTAG-3'), GAPDH (sense: 5'-CTTTGGCATTGTGGAAGGGCTC-3'; antisense: 5'-GCAGGGATGATGTTCTGGGCAG-3').

Experimental animal. All experiments utilized ICR mice (male, 6-8 week-old, total used animal $=25$ ) obtained from Experimental Animal Center, Soonchunhyang University. The mice were provided with a commercial diet and water ad libitum under controlled temperature, humidity and lighting conditions (light/dark cycle $12: 12$, and $22 \pm 2^{\circ} \mathrm{C}, 55 \pm 5 \%$ ). All experimental protocols were approved by the Administrative Panel on Laboratory Animal Care of Soonchunhyang University (permit no. SCH 15-0002-3). All possible efforts 
were made to avoid suffering of the rats and distress, and minimize the number used during the experiments. The euthanasia for all experimental animals was conducted utilizing general inhalants methods with Carbon dioxide $\left(\mathrm{CO}_{2}\right)$ under the guideline of our Laboratory Animal Care Permits. During the experiments of in vivo study, all animal health, discomforts and behavior condition were monitored minimum 1 time per each day until animal euthanasia during in vivo animal experiments to follow ARRIVE checklist (https://www.nc3rs. org.uk/arrive-guidelines). There is no found the death for all animals during this study.

TPA-induced ear edema. TPA-induced skin animal models were produced as described elsewhere $(22,24)$. TPA is known as the strongest promoter of skin inflammation and well described the characteristics of TPA in skin inflammations (28). To assess the effects of Tat-Trx1 against TPA-induced ear edema, the mice were divided into five groups ( $\mathrm{n}=5$ per group) as follows: control group; TPA-treated group; Tat-Trx1-treated group; Trx1-treated group; and Tat peptide-treated group. TPA $(1.0 \mu \mathrm{g})$ dissolved in $20 \mu \mathrm{l}$ of acetone was applied to the inner and outer surfaces of the ears of the mice every day for 3 days. Tat-Trx1 $(10 \mu \mathrm{g})$ protein was topically applied to the ears of mice every day $1 \mathrm{~h}$ after TPA treatment. Twenty-four hours after the final treatment with TPA and Tat-Trx1 (experimental duration $=4$ days), all mice $(n=25)$ were euthanized utilizing general inhalants methods in the euthanasia chamber for fill rate of $30-70 \%$ of the chamber volume per minute with Carbon dioxide $\left(\mathrm{CO}_{2}\right)$ according AVMA Guidelines for the Euthanasia of Animals (29). Then, the ear biopsies were obtained. Ear thicknesses were measured using a digital thickness gauge (Mitutoyo Corporation). Ear weights were measured after 5 $\mathrm{mm}$ diameter ear biopsies were obtained from each group using a punch (Kai Industries).

Immunohistochemistry. For histological analysis, ear biopsies were fixed in $4 \%$ paraformaldehyde, embedded in paraffin, sectioned at a thickness of $5 \mu \mathrm{m}$, and then stained with hematoxylin and eosin $(22,24)$.

Statistical analysis. Data are expressed as the mean \pm SEM of three experiments. The statistical significance analyzed using one-way ANOVA followed by a Bonferroni post hoc test. $\mathrm{P}$-value $<0.05$ was considered as significant.

\section{Results}

Transduction of purified Tat-Trxl into Raw 264.7 cells. We constructed a fusion protein Tat-Trx 1 and purified it. As expected, one single band was detected for the purified protein (Fig. 1A). As shown in Fig. 1B and C, Tat-Trx1 transduced into Raw 264.7 cells time-dependently and its level was maintained for $6 \mathrm{~h}$. However, Trx1 did not transduce into Raw 264.7 cells. Transduced Tat-Trx1 was distributed in the cytoplasm and nucleus (Fig. 1D).

Tat-Trxlinhibits LPS-induced ROS production and DNA fragmentation. It is known that LPS can ROS production and DNA fragmentation and lead to cell death $(11,12)$. Thus, we determined effects of Tat-Trx1 on ROS production and DNA fragmentation. As shown in Fig. 2A and B, ROS production and DNA fragmentation levels were increased in Raw 264.7 cells treated with LPS only. However, Tat-Trx1 markedly prevented such increases of ROS production and DNA fragmentation, whereas ROS production and DNA fragmentation levels showed no significant difference between Trx1 and Tat peptide treated cells.

Tat-Trx1 inhibits LPS-induced activation of MAPK and $N F-\kappa B$ signaling. Suppressing MAPK (p38, JNK, and ERK) and $\mathrm{NF}-\kappa \mathrm{B}$ activation is important for inhibiting inflammation in LPS-activated Raw 264.7 cells (30-32). Thus, we examined whether Tat-Trx1 could inhibit the activation of MAPK and $\mathrm{NF}-\kappa \mathrm{B}$ in LPS-treated cells. As shown in Fig. 3A and B, $\mathrm{NF}-\kappa \mathrm{B}$ (p65) and MAPK expression levels were markedly increased in LPS-exposed Raw 264.7 cells, whereas Tat-Trx1 significantly reduced expression levels of p65 and MAPK in LPS-exposed Raw 264.7 cells. The expression pattern of Akt after LPS treatment was similar to that of MAPK (Fig. 3C). However, there was no significant difference the expression of NF-кB, MAPK, and Akt in cells treated with Trx1 or Tat peptide.

We also determined levels of Bcl-2, Bax, caspase-3, and cleaved caspase- 3 proteins. Bax and cleaved caspase- 3 protein expression levels were increased in LPS-treated Raw 264.7 cells, whereas Tat-Trx1 reduced these protein expression levels in LPS-treated cells. In contrast, Tat-Trx 1 markedly increased Bcl-2 and caspase-3 protein expression levels in LPS-treated cells, whereas there was no significant difference the expression of Bcl-2, Bax, caspase-3, and cleaved caspase-3 proteins in cells treated with Trx1 or Tat peptide (Fig. 4).

Tat-Trx1 inhibits LPS-induced inflammation. We further investigated whether Tat-Trx1 inhibited LPS-induced inflammatory responses in Raw 264.7 cells. As shown in Fig. 5A and B, LPS drastically increased the expression of pro-inflammatory mediator proteins (iNOS and COX-2) and cytokine genes (IL-1 $\beta$, IL-6, and TNF- $\alpha$ ) in Raw 264.7 cells. In contrast, Tat-Trx1 significantly reduced these inflammation factors in cells. However, Trx1 or Tat peptide did not change the expression of pro-inflammatory mediators or cytokines.

Effect of Tat-Trxl in TPA-induced animal model. TPA-induced ear edema animal model is generally used for skin inflammation study. Thus, we examined the anti-inflammatory effect of Tat-Trx 1 in TPA-induced ear edema animal model. We designed the experiment to induced mice ear edema using TPA. As shown in Fig. 6A, TPA ( $1 \mu$ g/ear) was topically applied to mouse ears $1 \mathrm{~h}$ prior to Tat-Trx 1 treatment and then evaluate the effect of Tat-Trx1 on TPA-induced ear edema model. TPA markedly increased ear thickness and weight of mouse showing skin inflammation. However, Tat-Trx1 significantly inhibited skin inflammation, ear thickness, and weight (Fig. 6B and C).

We also determined the effect of Tat-Trx1 in TPA-exposed mouse model (Fig. 7). In TPA treated mouse ears, iNOS, COX-2, IL-1 $\beta$, IL-6, and TNF- $\alpha$ mRNA expression levels were markedly increased. However, Tat-Trx1 significantly reduced these mRNA expression levels in the animal model. However, iNOS, COX-2, IL-1 $\beta$, IL-6, and TNF- $\alpha$ mRNA expression 
A

$(\mathrm{kDa})$

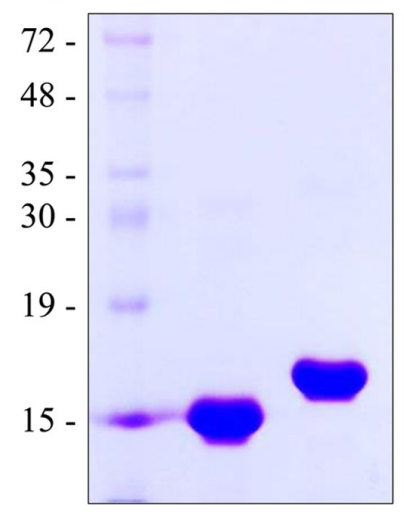

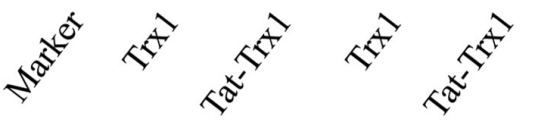

B
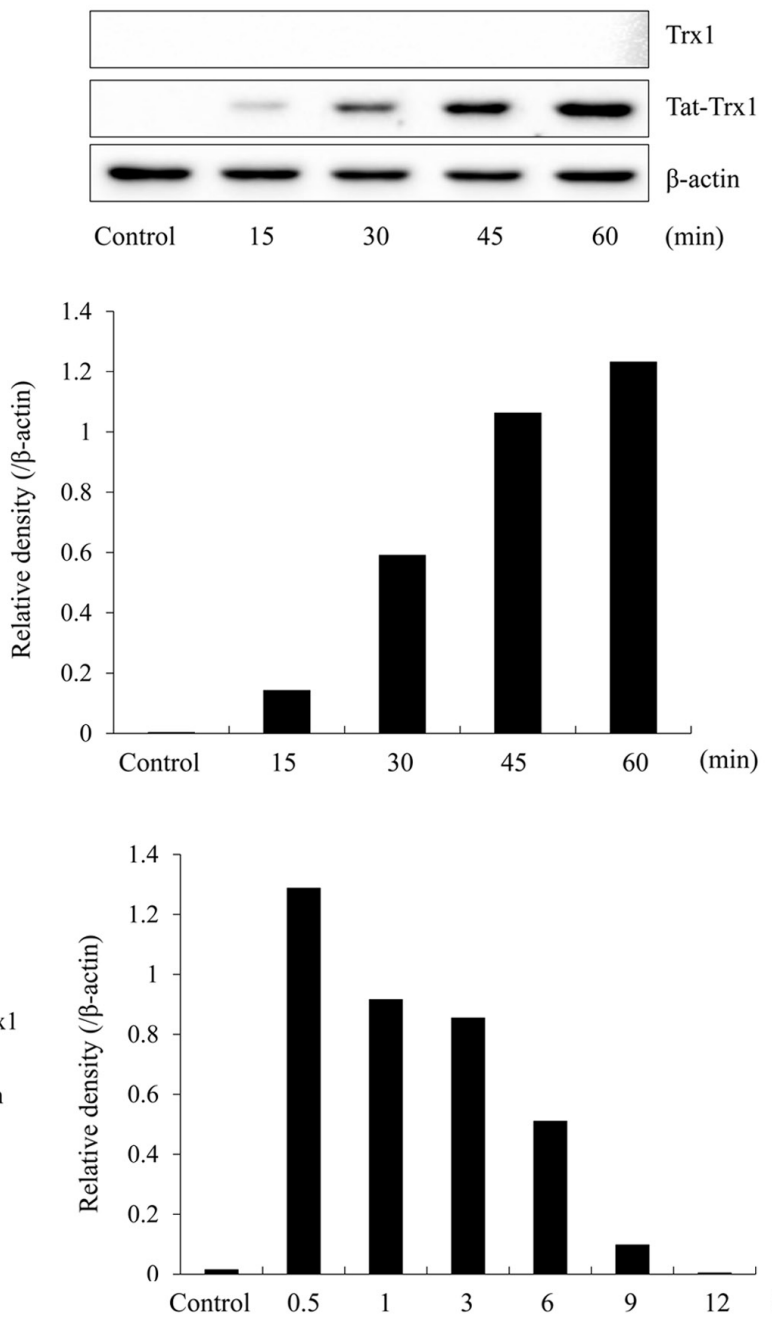

$\mathbf{D}$

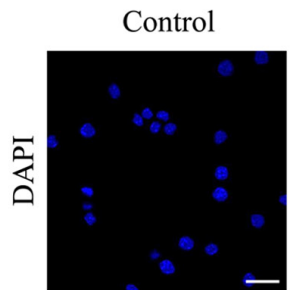

Tat-Trx1

$\operatorname{Trx} 1$
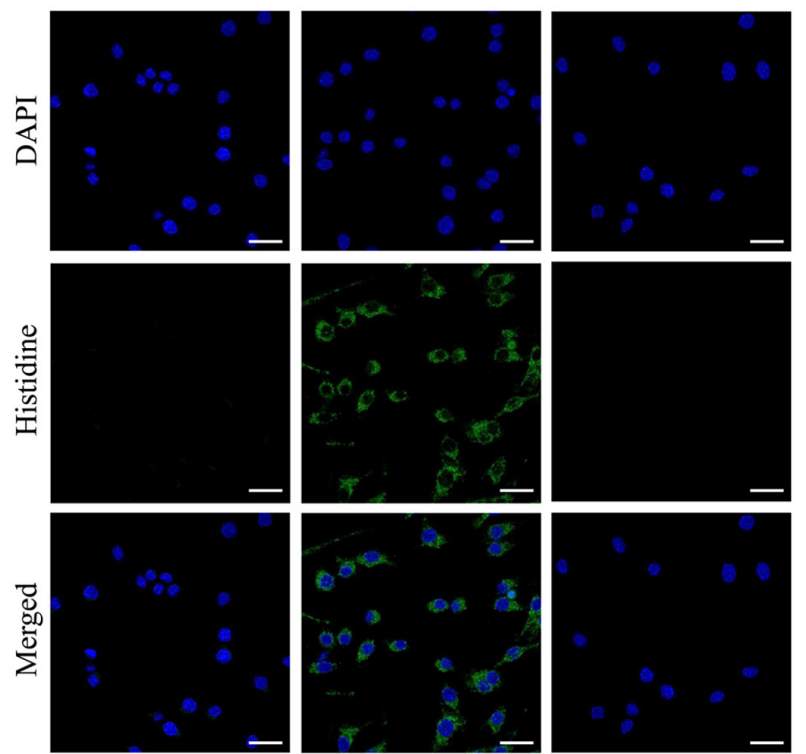

Figure 1. Purification and transduction of Tat-Trx1 protein. (A) Purified Tat-Trx1 and Trx1 proteins were identified by 15\% SDS-PAGE and western blotting. (B) Cell culture media were treated with Tat-Trx1 $(1 \mu \mathrm{M})$ for different time periods (15-60 min). (C) Intracellular stability of transduced Tat-Trx1. The cells were incubated for $12 \mathrm{~h}$ after transduction of Tat-Trx 1 for $1 \mathrm{~h}$. Transduction of Tat-Trx 1 was measured by western blotting and the intensity of the bands was measured by densitometry. (D) Cells were treated with Tat-Trx $1(1 \mu \mathrm{M})$ for $1 \mathrm{~h}$ and the cellular distribution of transduced Tat-Trx 1 was confirmed by fluorescence microscopy. Scale bar, $50 \mu \mathrm{m}$. Trx1, thioredoxin 1. 
A
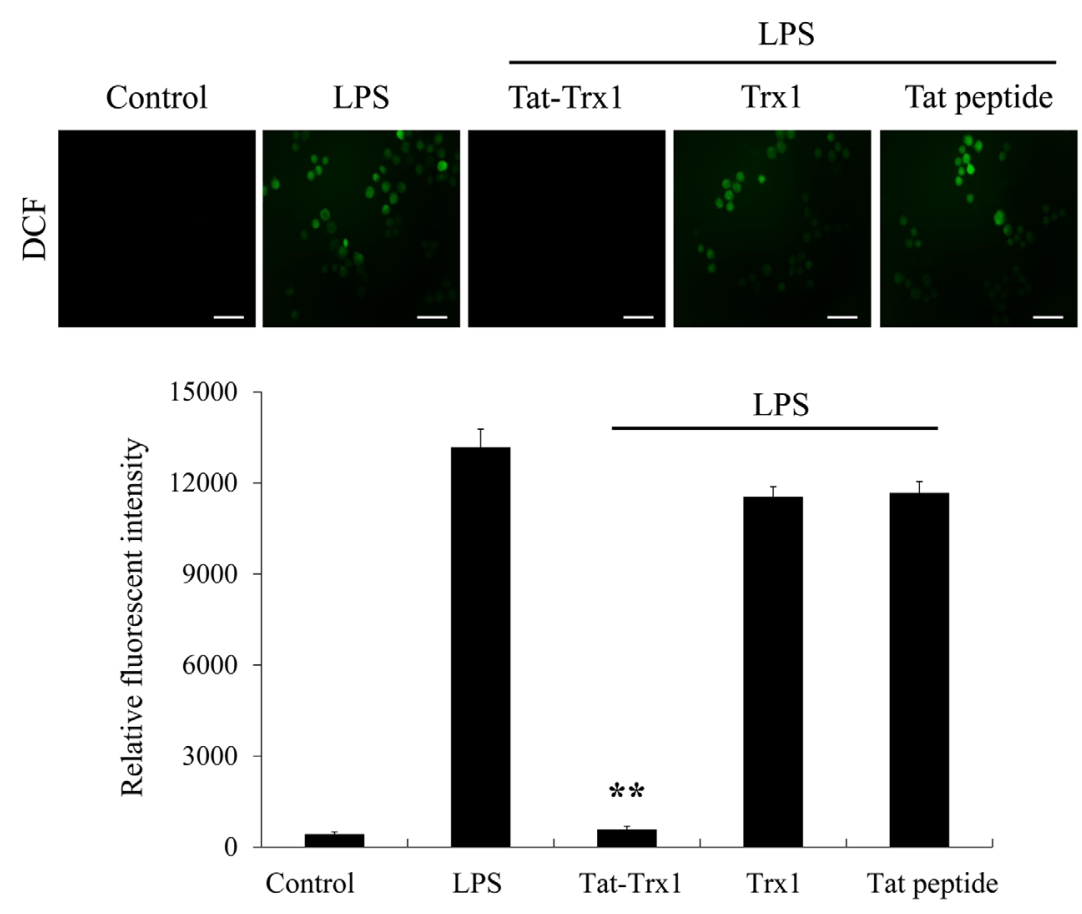

$\mathbf{B}$

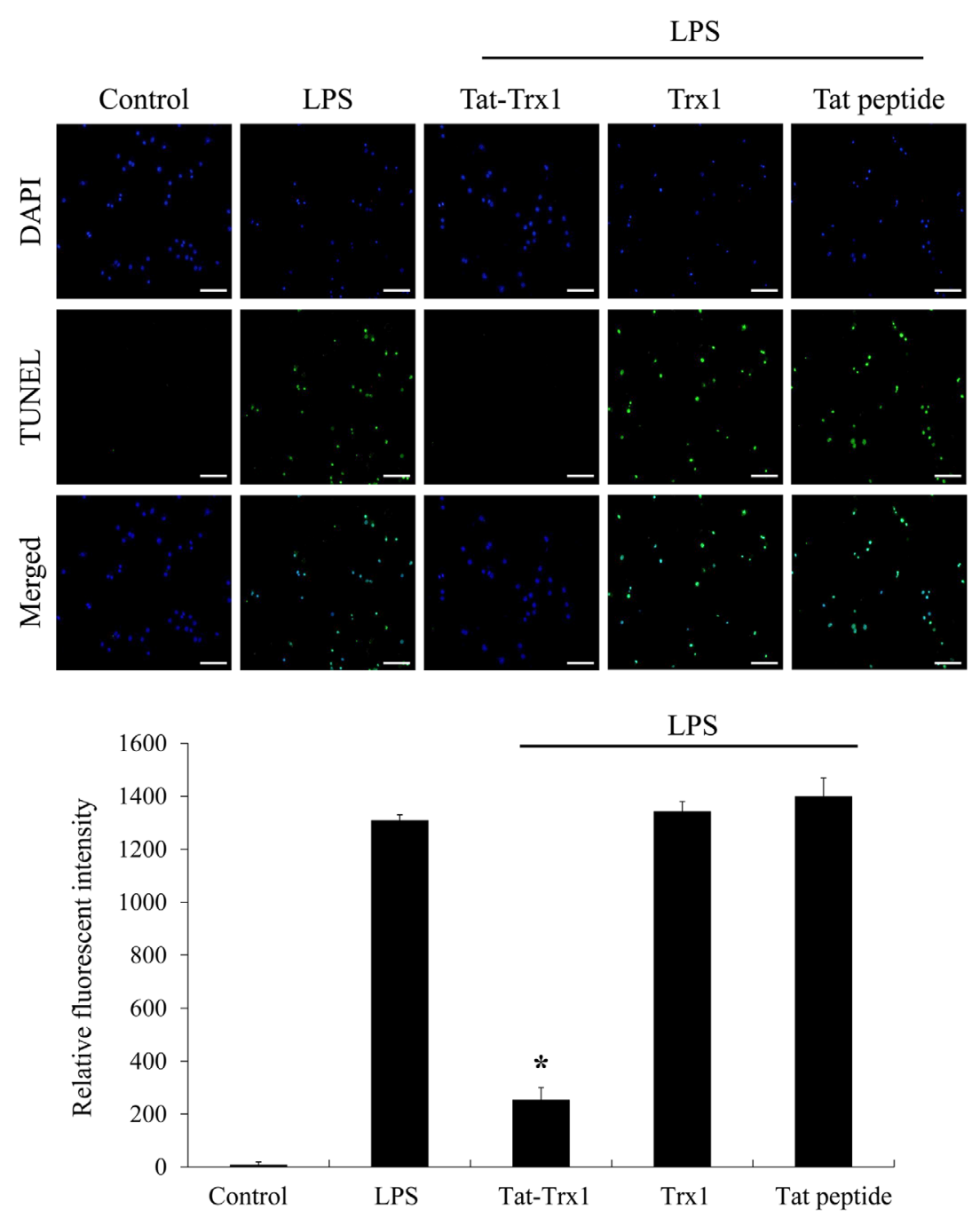

Figure 2. Effects of Tat-Trx1 on LPS-induced ROS production and DNA damage. Treatment with Tat-Trx1 $(1 \mu \mathrm{M})$ was followed by $1 \mathrm{~h}$ treatment with LPS $(1 \mu \mathrm{g} / \mathrm{ml})$. (A) Intracellular ROS levels were measured by DCF-DA staining and (B) DNA fragmentation was detected by TUNEL staining. The fluorescence intensity was measured using an ELISA plate reader. Scale bar, $50 \mu \mathrm{m}$. " $\mathrm{P}<0.05$ and ${ }^{* *} \mathrm{P}<0.01$ vs. LPS-treated cells. DCF-DA, 2',7'-dichlorofluorescein diacetate; LPS, lipopolysaccharide; ROS, reactive oxygen species; Trx1, thioredoxin 1. 
A

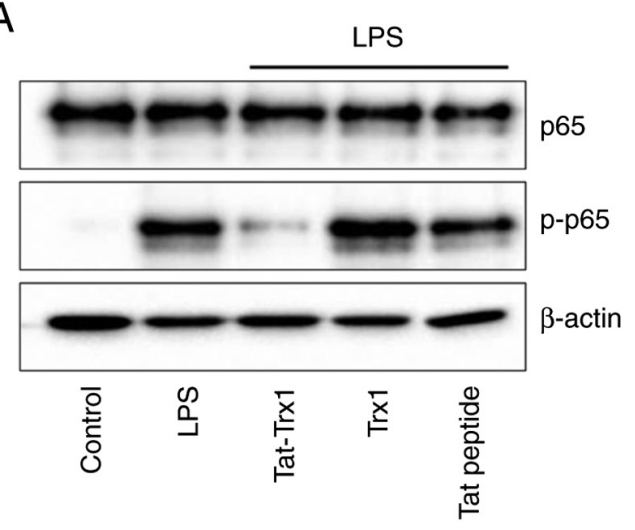

B

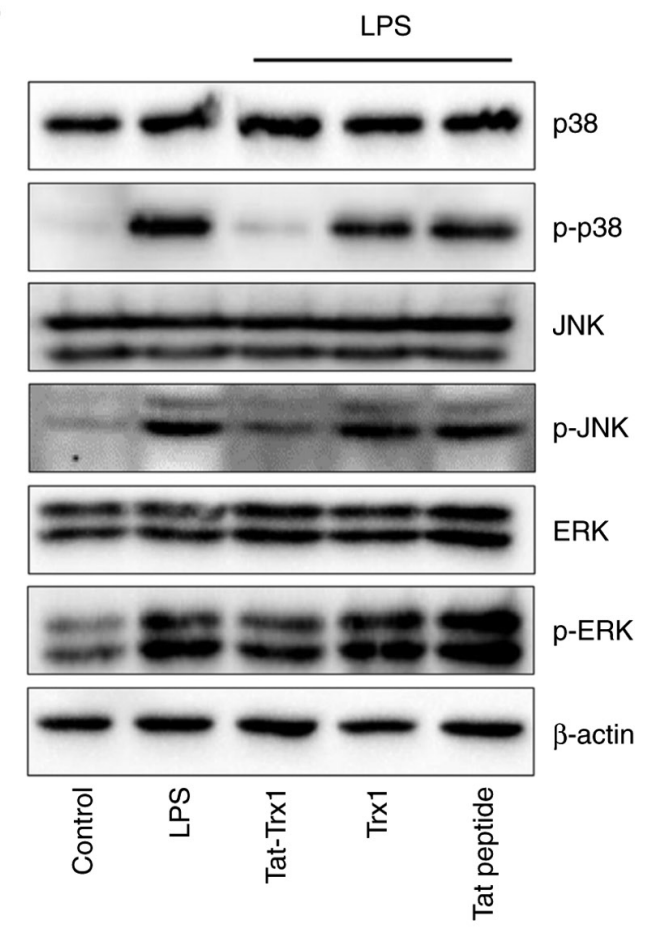

C

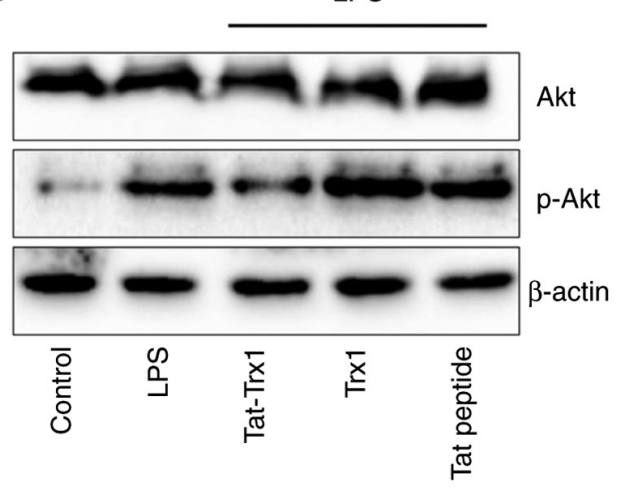

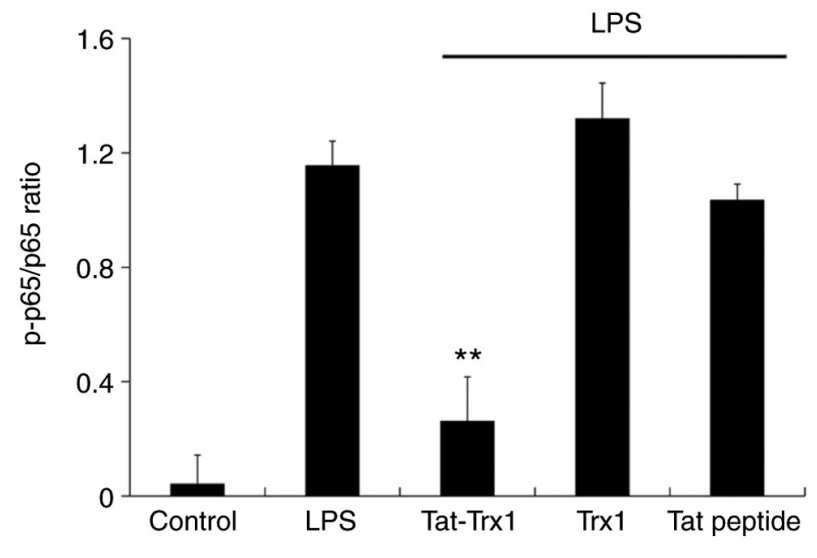
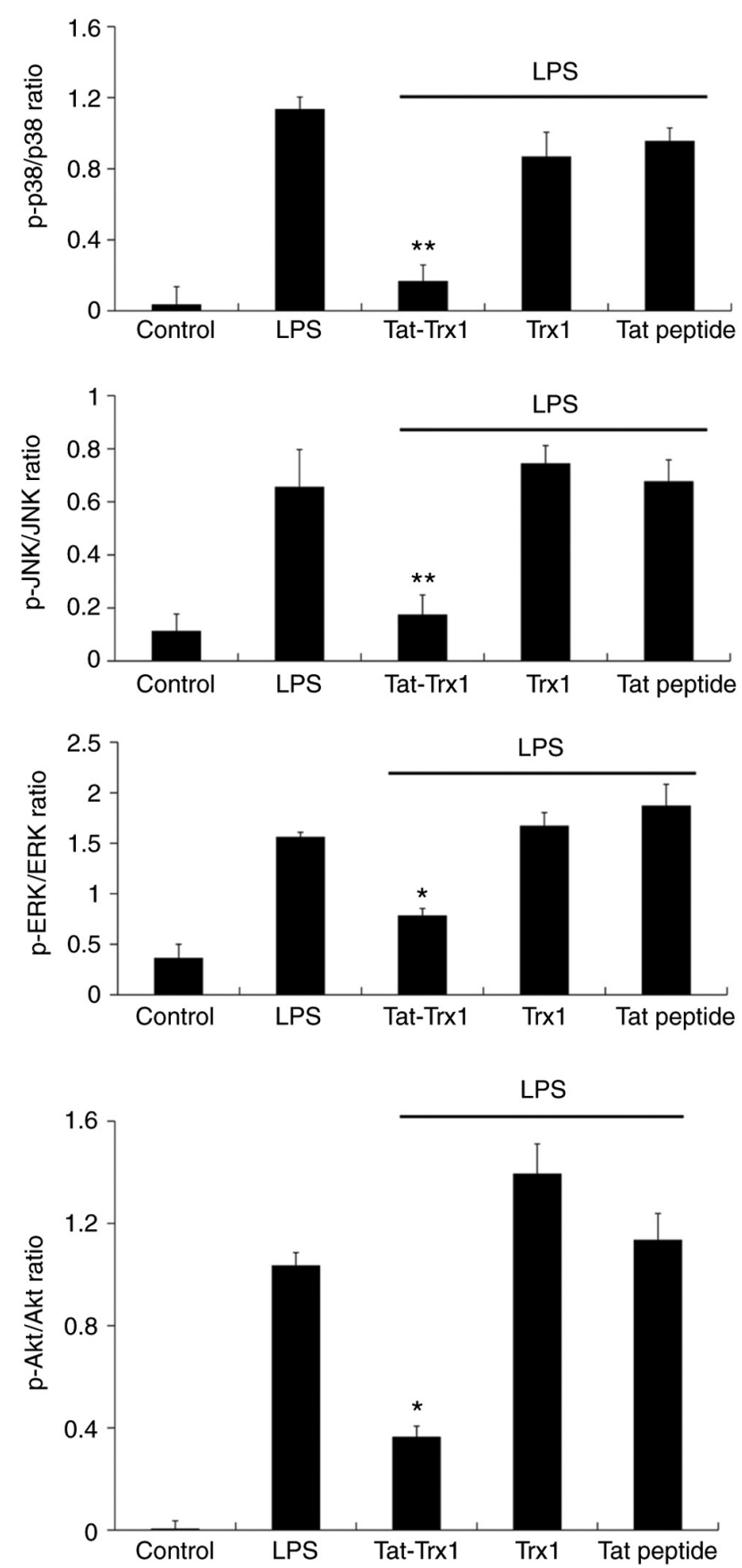

Figure 3. Effects of Tat-Trx1 on LPS-induced NF-кB (p65), MAPK (p38, JNK and ERK) and Akt phosphorylation in Raw 264.7 cells. The cells were pretreated with Tat-Trx1 $(1 \mu \mathrm{M})$ for $1 \mathrm{~h}$ and then treated with LPS $(1 \mu \mathrm{g} / \mathrm{ml})$. Phosphorylation levels of (A) p65, (B) MAPK (p38, JNK and ERK) and (C) Akt were determined by western blotting. The band intensity was measured by densitometry. ${ }^{*} \mathrm{P}<0.05$ and ${ }^{* *} \mathrm{P}<0.01$ vs. LPS-treated cells. LPS, lipopolysaccharide; p-, phosphorylated; Trx1, thioredoxin 1. 

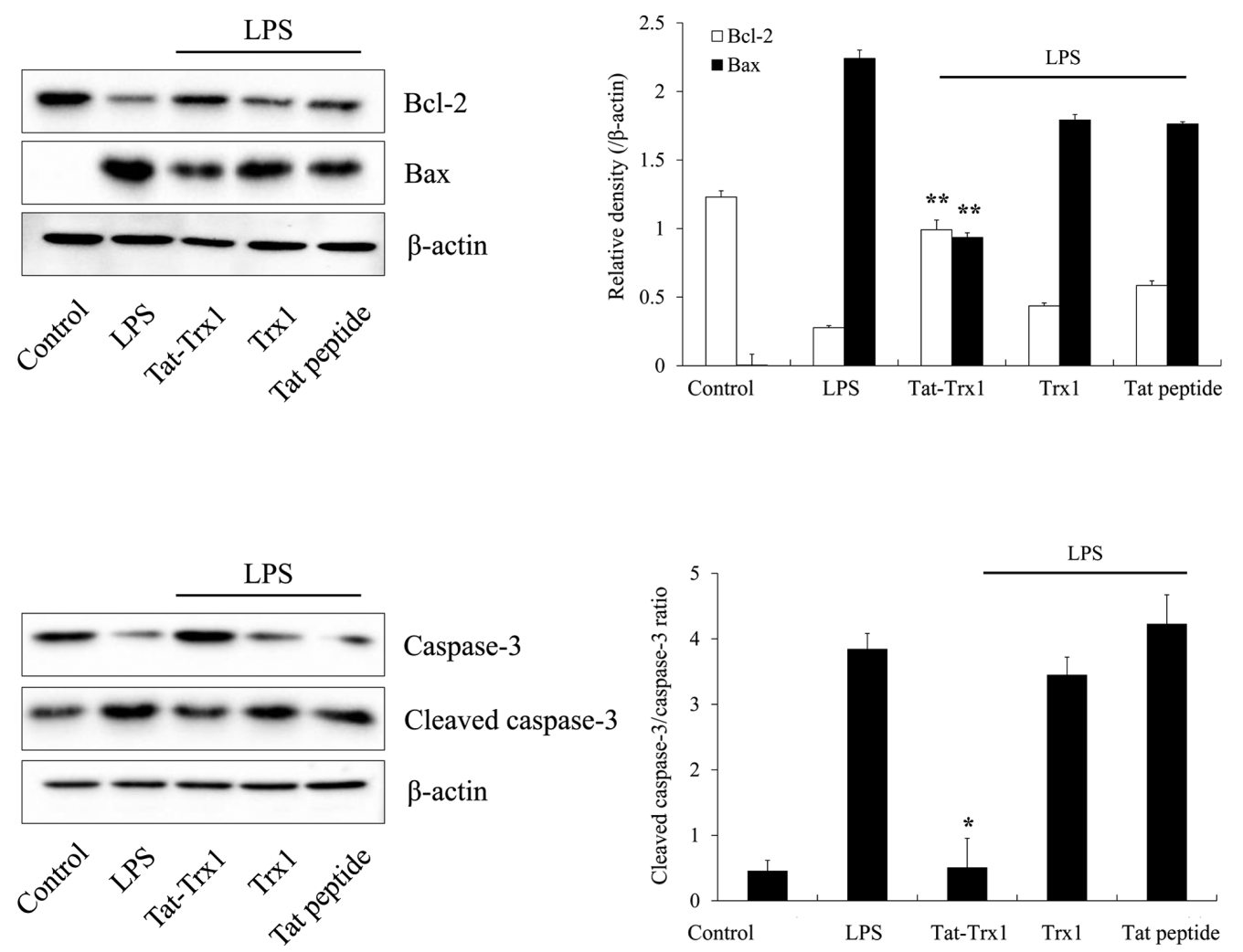

Figure 4. Effect of Tat-Trx1 on LPS-induced Bcl-2, Bax, caspase-3 and cleaved caspase-3 production in Raw 264.7 cells. The cells were pretreated with Tat-Trx $1(1 \mu \mathrm{M})$ for $1 \mathrm{~h}$ and then treated with LPS $(1 \mu \mathrm{g} / \mathrm{ml})$. The production levels of Bcl-2, Bax, caspase- 3 and cleaved caspase- 3 were determined by western blotting. The band intensity was measured by densitometry. " $\mathrm{P}<0.05$ and ${ }^{* * *} \mathrm{P}<0.01$ vs. LPS-treated cells. LPS, lipopolysaccharide; Trx 1 , thioredoxin 1 .

A

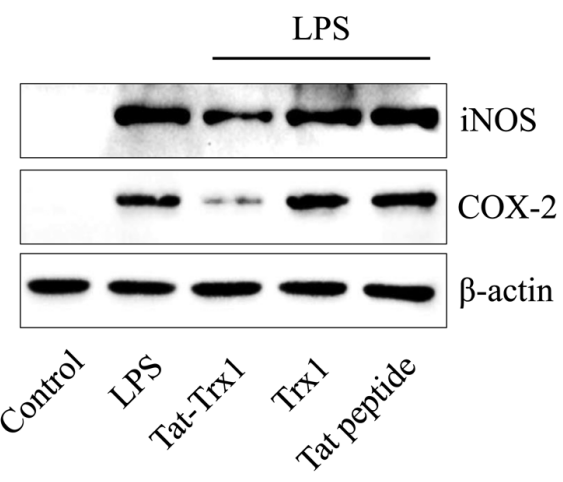

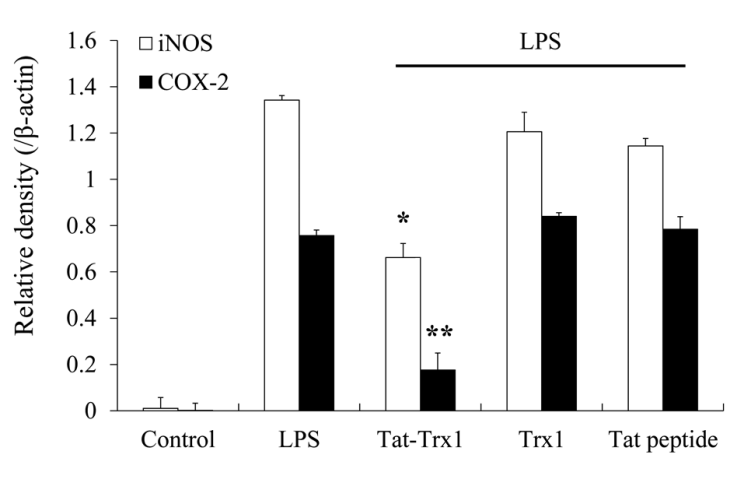

B
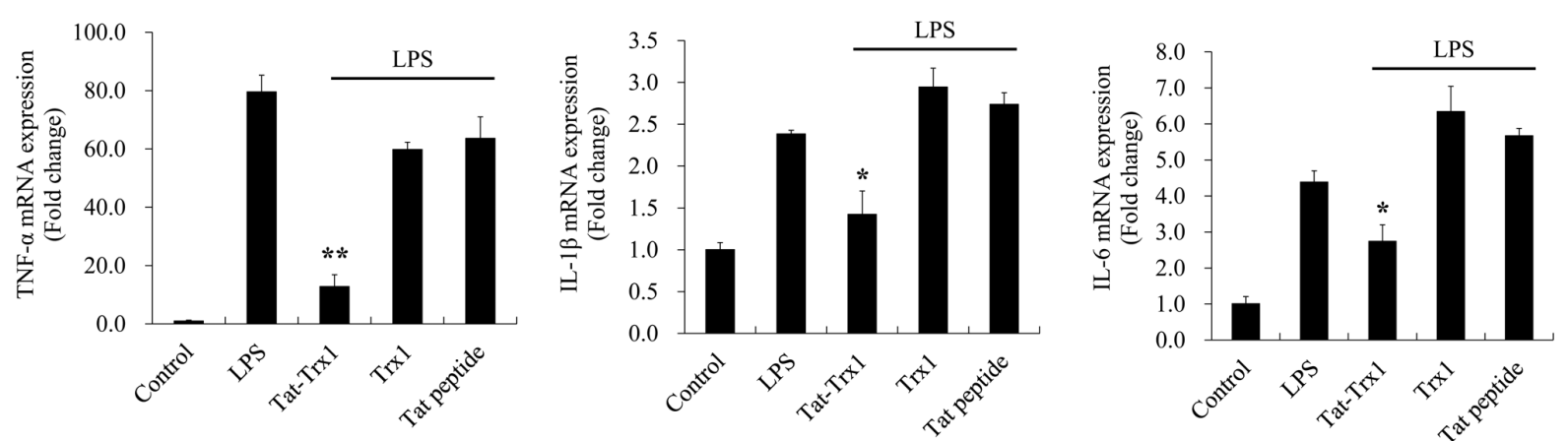

Figure 5. Effects of Tat-Trx 1 on LPS-induced inflammatory responses in Raw 264.7 cells. The cells were treated with Tat-Trx $1(1 \mu \mathrm{M})$ for $1 \mathrm{~h}$ before being exposed to LPS $(1 \mu \mathrm{g} / \mathrm{ml})$. (A) Protein expression levels of COX-2 and iNOS were analyzed by western blotting. The band intensity was measured by densitometry. (B) mRNA levels of cytokines were determined using reverse transcription-quantitative PCR. The mRNA levels were normalized to GAPDH and subsequently represented as the fold change relative to the control group. ${ }^{*} \mathrm{P}<0.05$ and ${ }^{* *} \mathrm{P}<0.01$ vs. LPS-treated cells. COX-2, cyclooxygenase-2; LPS, lipopolysaccharide; iNOS, inducible nitric oxide synthase; Trx1, thioredoxin 1. 


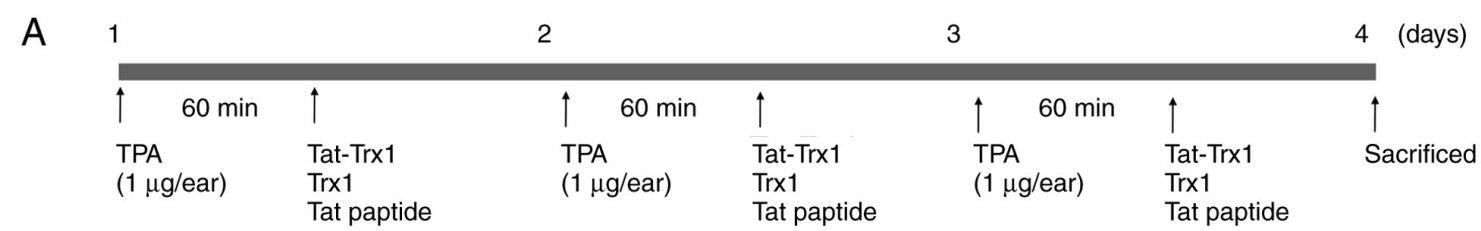

B

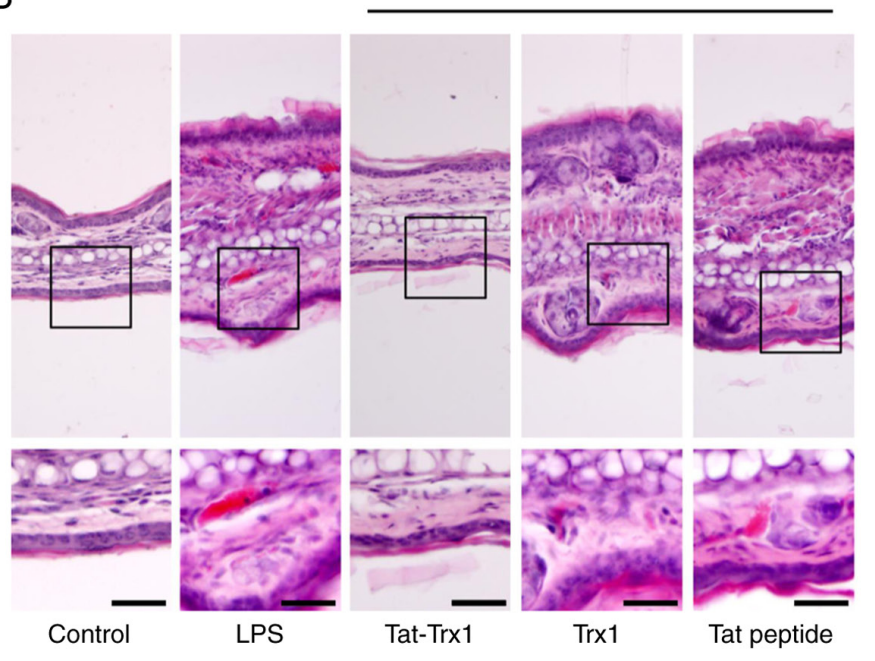

C
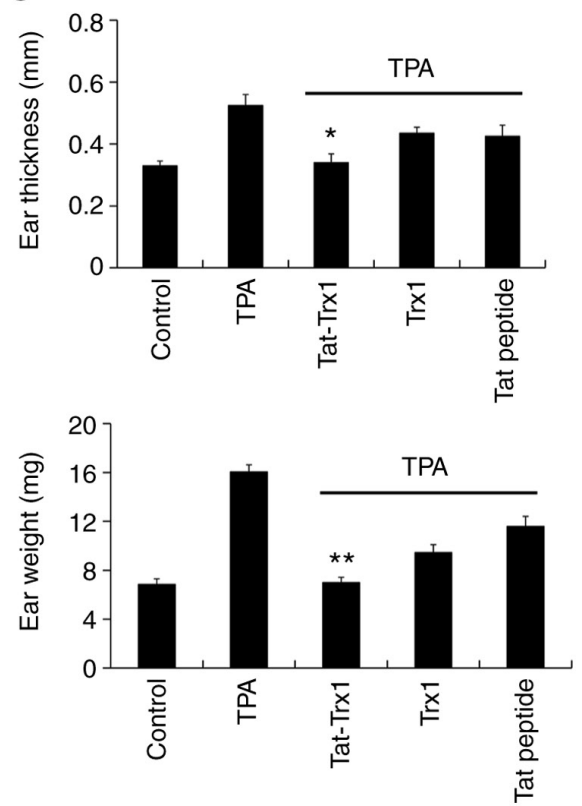

Figure 6. Effects of Tat-Trx 1 on TPA-induced mice ear edema. Ears of mice were treated with TPA $(1 \mu \mathrm{g} / \mathrm{ear})$ once a day for 3 days. Tat-Trx 1 protein $(10 \mu \mathrm{g})$ was topically applied to mice ears $1 \mathrm{~h}$ prior to TPA exposure over 3 days. (A) Schematic representation of the experimental procedure. Protective effects of Tat-Trx1 were demonstrated by (B) hematoxylin and eosin staining, as well as changes in (C) ear weight and ear thickness in a TPA-induced mice ear edema model. Scale bar, $50 \mu \mathrm{m}$. ${ }^{*} \mathrm{P}<0.05$ and $^{* *} \mathrm{P}<0.01$ vs. TPA-treated mice. TPA, 12-O-tetradecanoylphorbol-13-acetate; Trx1, thioredoxin 1.
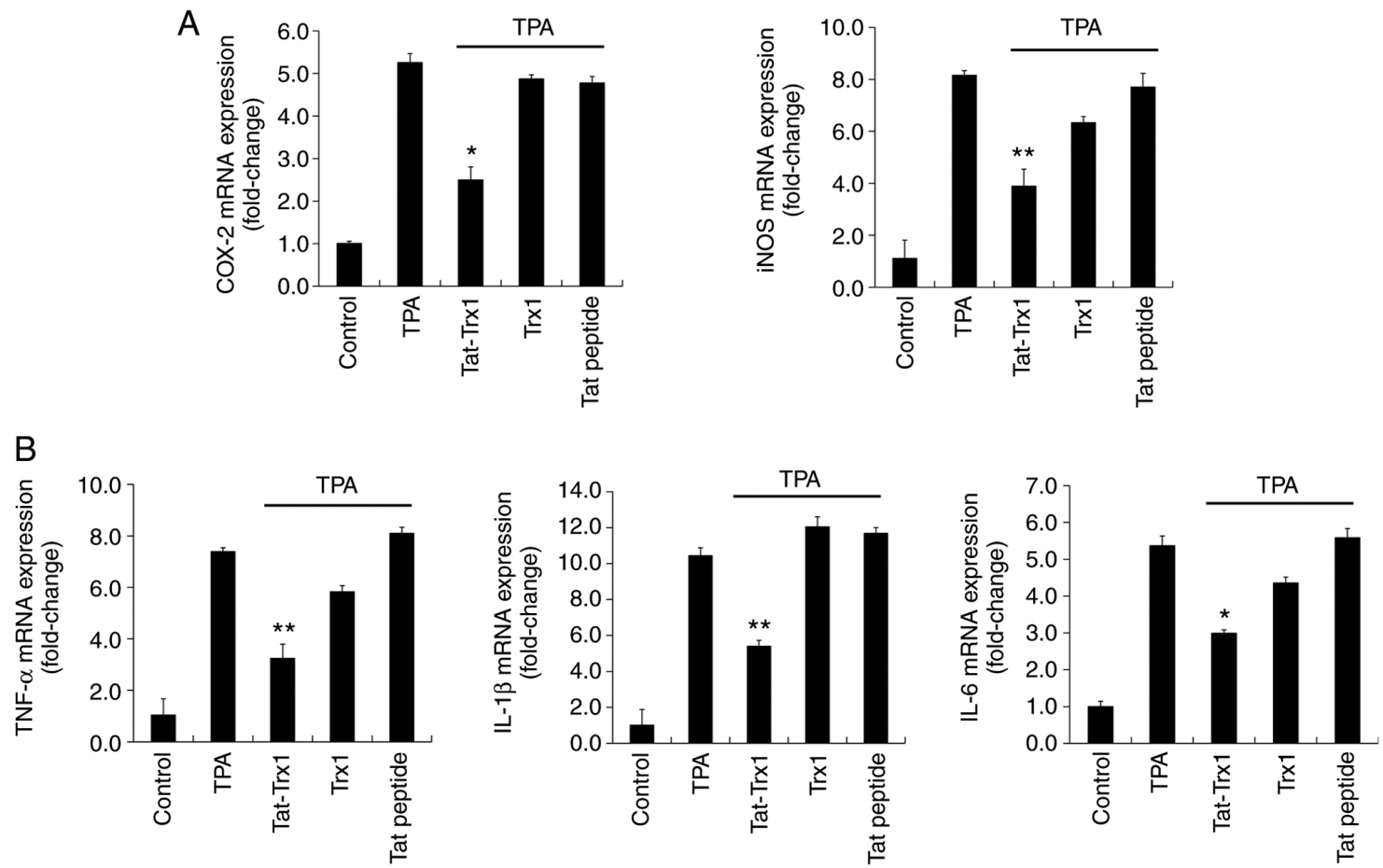

Figure 7. Effects of Tat-Trx1 on TPA-induced pro-inflammatory mediator (iNOS and COX-2) and cytokine (IL-1 $\beta$, IL- 6 and TNF- $\alpha$ ) expression in mice ears. Mice were stimulated with TPA $(1 \mu \mathrm{g} / \mathrm{ear})$ after which Tat-Trx $1(10 \mu \mathrm{g})$ was topically applied to mice ear for 3 days. The mRNA levels of (A) pro-inflammatory mediators and (B) cytokines were determined using reverse transcription-quantitative PCR. The mRNA levels were normalized to GAPDH and subsequently represents as the fold change relative to the control group. ${ }^{*} \mathrm{P}<0.05$ and $^{* * *} \mathrm{P}<0.01 \mathrm{vs}$. TPA-treated mice. COX-2, cyclooxygenase-2; iNOS, inducible nitric oxide synthase; TPA, 12-O-tetradecanoylphorbol-13-acetate; Trx1, thioredoxin 1. 
levels showed no significant difference in Trx 1 or Tat peptide treated group compared to those in the TPA treated group.

\section{Discussion}

Inflammatory response plays an important role in the defense against external stimuli including microbial pathogens and chemicals. Also, inflammatory response can lead to various diseases including neurodegenerative diseases (33-36). It is well known that Trx1 is a redox regulating protein with a critical function in cell growth, gene expression, and apoptosis $(37,38)$. In addition, Trx 1 exerts beneficial role in cell survival from oxidative stress due to its antioxidant and anti-inflammatory effects (39-41). Therefore, we investigated the anti-inflammatory effect of $\operatorname{Trx} 1$ in macrophages and an animal model. Since Tat peptide can transduce into cells cross the cellular membrane due to its potential for membrane permeability with safety and nontoxic effect, it is widely used in protein delivery into cells (42-44). In this study, we fused a Tat peptide with human Trx 1 gene to produce a cell permeable Tat-Trx1 protein. Many reports have shown a beneficial effect of therapeutic transducible Tat fused proteins on cell survival both in vitro and in vivo $(22,25,45-50)$.

LPS plays a crucial role in inducing inflammatory responses, leading to various inflammatory diseases (51). LPS can also increase intracellular ROS levels in macrophages. High levels of ROS can induce inflammatory responses $(43,44)$. Previous studies have revealed that LPS can induce high levels of ROS and that antioxidants play a beneficial role against LPS-induced inflammation $(52,53)$. It has been reported that Trx1 can protect cells against damage caused by oxidative stress in various diseases due to its anti-oxidant function (21,54-56). In the present study, cell permeable fusion protein Tat-Trx1 transduced into macrophages and drastically reduced LPS-induced ROS generation and DNA damage, suggesting that Tat-Trx1 could play a beneficial role in cell survival against LPS-induced damage.

Many reports have shown that LPS can induce NF- $\kappa$ B activation and its upstream regulator, MAPK. MAPKs pathway can regulate inflammatory responses. Activated p65 can lead to the production of pro-inflammatory mediators and cytokines (14-17,57-61). Thus, it is widely believed that NF- $\kappa \mathrm{B}$ and MAPKs signaling is a promising target for treating inflammatory diseases. Here, we showed that Tat-Trx1 reduced NF- $\kappa$ B and MAPK activation caused by LPS, indicating that Tat-Trx1 could inhibit inflammation by regulating NF- $\kappa$ B and MAPKs signaling.

It is well described that TPA, a promotor of skin tumorigenesis, can induce inflammatory symptom and cancer development. In general, TPA-induced mouse model can be used to understand the inflammatory mechanism (28,62-65). Several studies have reported that TPA is a phorbol ester that promotes a direct activation of protein kinase $\mathrm{C}$ pathway, which results in elevated levels of prostaglandin $E_{2}$ and leukotriene $\mathrm{B}_{4}$ in applied to the skin. Also, TPA promotes the activation of MAPK pathway that lead to the expression of several important molecules for the inflammatory responses such as adhesion molecules, chemokines, and inflammatory mediators (66-69). In addition, other studies have shown that production levels of pro-inflammatory mediators and cytokines are markedly increased in TPA-induced inflammation model $(63,70,71)$. He et al (72) have shown that inflammatory responses in animal model can be quantified by measuring ear weight and ear thickness after treatment with natural compounds (Qi-Wei-Xiao-Yan-Tang: XYT). XYT can significantly ameliorate inflammatory responses in an animal model, suggesting that it can be used as a therapeutic agent (72). Topical application of various anti-inflammatory therapeutic agents can also significantly inhibit inflammation by suppressing inflammatory responses in a TPA-induced mouse model (73-75).

Results of the present study revealed that Tat-Trx1 markedly reduced TPA-induced ear thickness, weight, and inflammatory responses. Taken together, our results indicate that Tat-Trx1 can significantly prevent inflammation in macrophages and in an animal model by inhibiting the production of pro-inflammatory mediators and cytokines as well as NF- $\kappa$ B and MAPK activation. Therefore, Tat-Trx1 can be used as a therapeutic agent for treating diseases induced by inflammatory damage.

\section{Acknowledgements}

Not applicable.

\section{Funding}

The present study was supported by Basic Science Research Program (grant no. 2019R1A6A1A11036849) through the National Research Foundation of Korea (NRF) funded by the Ministry of Education.

\section{Availability of data and materials}

The datasets used and/or analyzed during the current study are available from the corresponding author on reasonable request.

\section{Authors' contributions}

EJY, MJS, WSE and SYC were involved in the conceptualization of the study. HJY, YJC, EJS, LRL and HJC performed the experiments, and acquired and analyzed the data. HJK, YHY, DWK and DSK produced the methodology of the animal model and concurrently conducted animal studies. SHL, SL, JP and KHH were responsible for data analysis and interpretation, and participated in the drafting of the manuscript. EJY and SYC confirmed the authenticity of all the raw data. WSE, MJS and SYC were involved in the writing and editing of the manuscript and provided final approval of the version to be published. All authors read and approved the final manuscript.

\section{Ethics approval and consent to participate}

The care of animals conformed to the Guide for the Care and Use of Laboratory Animals of the National Veterinary Research and Quarantine Service of Korea and the present study was approved by the Institutional Animal Care and Use Committee of Soonchunhyang University Cheonan, Chungcheongnam, Republic of Korea (approval no. SCH 15-0002-3). 


\section{Patient consent for publication}

Not applicable.

\section{Competing interests}

The authors declare that they have no competing interests.

\section{References}

1. Kolaczkowska E and Kubes P: Neutrophil recruitment and function in health and inflammation. Nat Rev Immunol 13: $159-175,2013$

2. Nathan C and Ding A: Nonresolving inflammation. Cell 140: 871-882, 2010.

3. Libby P, Ridker PM and Maseri A: Inflammation and atherosclerosis. Circulation 105: 1135-1143, 2002.

4. Straub RH and Schradin C: Chronic inflammatory systemic diseases: An evolutionary trade-off between acutely beneficia but chronically harmful programs. Evol Med Public Health 2016 37-51, 2016.

5. Grivennikov SI, Greten FR and Karin M: Immunity, inflammation, and cancer. Cell 140: 883-899, 2010.

6. Corriveau CC and Danner RL: Endotoxin as a therapeutic target in septic shock. Infect Agents Dis 2: 35-43, 1993.

7. Won AN, Kim SA, Ahn JY, Han JH, Kim CH, Lee JH and Kim DI: HO-1 induction by Selaginella tamariscina extract inhibits inflammatory response in lipopolysacchraride-stimulated RAW 264.7 macrophages. Evid Complement Alternat Med 2018: 7816923, 2018.

8. Fujihara M, Muroi M, Tanamoto K, Suzuki T, Azuma H and Ikeda $\mathrm{H}$ : Molecular mechanisms of macrophage activation and deactivation by lipopolysaccharide: Roles of the receptor complex. Pharmacol Ther 100: 171-194, 2003.

9. Duffield JS: The inflammatory macrophage: A story of Jekyll and Hyde. Clin Sci (Lond) 104: 27-38, 2003.

10. Korhonen R, Lahti A, Kankaanranta H and Moilanen E: Nitric oxide production and signaling in inflammation. Curr Drug Targets Inflamm Allergy 4: 471-479, 2005.

11. Luedde $\mathrm{T}$ and Schwabe RF: NF- $\kappa \mathrm{B}$ in the liver - linking injury, fibrosis and hepatocellular carcinoma. Nat Rev Gastroenterol Hepatol 8: 108-118, 2011.

12. Lee IT, Shih RH, Lin CC, Chen JT and Yang CM: Role of TLR4/NADPH oxidase/ROS-activated p38 MAPK in VCAM-1 expression induced by lipopolysaccharide in human renal mesangial cells. Cell Commun Signal 10: 33, 2012.

13. Kim HJ, Lee HS, Chong YH and Kang JL: p38 Mitogen-activated protein kinase up-regulates LPS-induced NF-kappaB activation in the development of lung injury and RAW 264.7 macrophages Toxicology 225: 36-47, 2006.

14. Zucoloto AZ, Manchope MF, Staurengo-Ferrari L, Pinho-Ribeiro FA, Zarpelon AC, Saraiva ALL, Cecílio NT, Alves-Filho JC, Cunha TM, Menezes GB, et al: Probucol attenuates lipopolysaccharide-induced leukocyte recruitment and inflammatory hyperalgesia: Effect on NF-KB activation and cytokine production. Eur J Pharmacol 809: 52-63, 2017.

15. Afonina IS, Zhong Z, Karin M and Beyaert R: Limiting inflammation-the negative regulation of NF- $\mathrm{KB}$ and the NLRP3 inflammasome. Nat Immunol 18: 861-869, 2017.

16. Pearson G, Robinson F, Beers Gibson T, Xu BE, Karandikar M, Berman K and Cobb MH: Mitogen-activated protein (MAP) kinase pathways: Regulation and physiological functions. Endocr Rev 22: 153-183, 2001.

17. Scherle PA, Jones EA, Favata MF, Daulerio AJ, Covington MB, Nurnberg SA, Magolda RL and Trzaskos JM: Inhibition of MAP kinase kinase prevents cytokine and prostaglandin $\mathrm{E}_{2}$ production in lipopolysaccharide-stimulated monocytes. J Immunol 161 5681-5686, 1998

18. Loftis JM,Choi D,Hoffman W and Huckans MS: Methamphetamine causes persistent immune dysregulation: A cross-species, translational report. Neurotox Res 20: 59-68, 2011.

19. Bai J, Nakamura H, Kwon YW, Tanito M, Ueda S, Tanaka T, Hattori I, Ban S, Momoi T, Kitao Y, et al: Does thioredoxin-1 prevent mitochondria- and endoplasmic reticulum-mediated neurotoxicity of 1-methyl-4-phenyl-1,2,3,6-tetrahydropyridine? Antioxid Redox Signal 9: 603-608, 2007.
20. Wu XL, Li X, Li Y, Kong LP, Fang JL, Zhou XS, Li M, Jia JJ and Bai J: The overexpression of Thioredoxin-1 suppressing inflammation induced by methamphetamine in spleen. Drug Alcohol Depend 159: 66-71, 2016

21. Chen G, Li X, Huang M, Li M, Zhou X, Li Y and Bai J. Thioredoxin-1 increases survival in sepsis by inflammatory response through suppressing endoplasmic reticulum stress. Shock 46: 67-74, 2016.

22. Yeo HJ, Shin MJ, You JH, Kim JS, Kim MY, Kim DW, Kim DS, Eum WS and Choi SY: Transduced Tat-CIAPIN1 reduces the inflammatory response on LPS- and TPA-induced damages. BMB Rep 52: 695-699, 2019.

23. Youn GS, Park JK, Lee CY, Jang JH, Yun SH, Kwon HY, Choi SY and Park J: MicroRNA-22 negatively regulates LPS-induced inflammatory responses by targeting HDAC6 in macrophages. BMB Rep 53: 223-228, 2020.

24. Shin MJ, Kim DW, Choi YJ, Cha HJ, Lee SH, Park J, Han KH, Eum WS and Choi SY: PEP-1-GLRX1 protein exhibits anti-inflammatory effects by inhibiting the activation of MAPK and NF- $\mathrm{KB}$ pathways in Raw 264.7 cells. BMB Rep 53: 106-111, 2020.

25. Shin MJ, Kim DW, Lee YP, Ahn EH, Jo HS, Kim DS, Kwon OS, Kang TC, Cho YJ, Park J, et al: Tat-glyoxalase protein inhibits against ischemic neuronal cell damage and ameliorates ischemic injury. Free Radic Biol Med 67: 195-210, 2014.

26. Kim SJ, Shin MJ, Kim DW, Yeo HJ, Yeo EJ, Choi YJ, Sohn EJ, Han KH, Park J, Lee KW, et al: Tat-biliverdin reductase A exerts a protective role in oxidative stress-induced hippocampa neuronal cell damage by regulating the apoptosis and MAPK signaling. Int J Mol Sci 21: 2672, 2020.

27. Livak KJ and Schmittgen TD: Analysis of relative gene expression data using real-time quantitative PCR and the 2(-Delta Delta C(T)) Method. Methods 25: 402-408, 2001.

28. Stanley PL, Steiner S, Havens M and Tramposch KM: Mouse skin inflammation induced by multiple topical applications of 12-O-tetradecanoylphorbol-13-acetate. Skin Pharmacol 4: 262-271, 1991.

29. American Veterinary Medical Association: AVMA Guidelines for the Euthanasia of Animals: 2020 Edition. https://www.avma. org/KB/Policies/Documents/euthanasia.pdf. Accessed March 2020.

30. Shou J, Kong X, Wang X, Tang Y, Wang C, Wang M, Zhang L, Liu Y, Fei C, Xue F, et al: Tizoxanide inhibits inflammation in LPS-activated RAW264.7 macrophages via the suppression of NF- $\kappa$ B and MAPK activation. Inflammation 42: 1336-1349, 2019.

31. Barton GM and Medzhitov R: Toll-like receptor signaling pathways. Science 300: 1524-1525, 2003.

32. Langford MP, McGee DJ, Ta KH, Redens TB and Texada DE: Multiple caspases mediate acute renal cell apoptosis induced by bacterial cell wall components. Ren Fail 33: 192-206, 2011.

33. Medzhitov R: Origin and physiological roles of inflammation. Nature 454: 428-435, 2008.

34. Tsaryk R, Peters K, Barth S, Unger RE, Scharnweber D and Kirkpatrick CJ: The role of oxidative stress in pro-inflammatory activation of human endothelial cells on Ti6Al4V alloy. Biomaterials 34: 8075-8085, 2013.

35. Ferrero-Miliani L, Nielsen OH, Andersen PS and Girardin SE: Chronic inflammation: Importance of NOD2 and NALP3 in interleukin-1beta generation. Clin Exp Immunol 147: 227-235, 2007.

36. Glass CK, Saijo K, Winner B, Marchetto MC and Gage FH: Mechanisms underlying inflammation in neurodegeneration. Cell 140: 918-934, 2010

37. Booze ML, Hansen JM and Vitiello PF: A novel mouse mode for the identification of thioredoxin-1 protein interactions. Free Radic Biol Med 99: 533-543, 2016

38. Susanti D, Wong JH, Vensel WH, Loganathan U, DeSantis R, Schmitz RA, Balsera M, Buchanan BB and Mukhopadhyay B: Thioredoxin targets fundamental processes in a methane-producing archaeon, Methanocaldococcus jannaschii. Proc Natl Acad Sci USA 111: 2608-2613, 2014

39. Nadeau PJ, Charette SJ, Toledano MB and Landry J: Disulfide Bond-mediated multimerization of Ask 1 and its reduction by thioredoxin-1 regulate $\mathrm{H}(2) \mathrm{O}(2)$-induced c-Jun $\mathrm{NH}(2)$-terminal kinase activation and apoptosis. Mol Biol Cell 18: 3903-3913, 2007.

40. Ueda S, Masutani H, Nakamura H, Tanaka T, Ueno M and Yodoi J: Redox control of cell death. Antioxid Redox Signal 4: 405-414, 2002. 
41. Couchie D, Vaisman B, Abderrazak A, Mahmood DFD, Hamza MM, Canesi F, Diderot V, El Hadri K, Nègre-Salvayre A, Le Page A, et al: Human plasma thioredoxin-80 increases with age and in $\mathrm{ApoE}^{-/-}$mice induces inflammation, angiogenesis, and atherosclerosis. Circulation 136: 464-475, 2017.

42. Cerrato CP, Pirisinu M, Vlachos EN and Langel Ü: Novel cell-penetrating peptide targeting mitochondria. FASEB J 29: 4589-4599, 2015

43. Moon JI, Han MJ, Yu SH, Lee EH, Kim SM, Han K, Park CH and Kim CH: Enhanced delivery of protein fused to cell penetrating peptides to mammalian cells. BMB Rep 52: 324-329, 2019.

44. Li Q, Hao X, Zaidi SSA, Guo J, Ren X, Shi C, Zhang W and Feng Y: Oligohistidine and targeting peptide functionalized TAT-NLS for enhancing cellular uptake and promoting angiogenesis in vivo. J Nanobiotechnology 16: 29, 2018.

45. Wu H, You C, Chen F, Jiao J, Gao Z, An P, Sun B and Chen R: Enhanced cellular uptake of near-infrared triggered targeted nanoparticles by cell-penetrating peptide TAT for combined chemo/photothermal/photodynamic therapy. Mater Sci Eng C 103: 109738, 2019

46. Yue LH, Zhao YL, Chen J and Lu DR: Effect of fusion protein TAT and heme oxygenase-1 on liver sinusoidal endothelial cells apoptosis during preservation injury. Chin Med J (Engl) 123: 68-73, 2010

47. Kubo E, Fatma N, Akagi Y, Beier DR, Singh SP and Singh DP TAT-mediated PRDX6 protein transduction protects against eye lens epithelial cell death and delays lens opacity. Am J Physiol Cell Physiol 294: C842-C855, 2008

48. Kim HR, Kim DW, Jo HS, Cho SB, Park JH, Lee CH, Choi YJ, Yeo EJ, Park SY, Kim ST, et al: Tat-biliverdin reductase A inhibits inflammatory response by regulation of MAPK and $\mathrm{NF}-\kappa \mathrm{B}$ pathways in Raw 264.7 cells and edema mouse model. Mol Immunol 63: 355-366, 2015.

49. Yeo HJ, Shin MJ, Yeo EJ, Choi YJ, Kim DW, Kim DS, Eum WS and Choi SY: Tat-CIAPIN1 inhibits hippocampal neuronal cell damage through the MAPK and apoptotic signaling pathways. Free Radic Biol Med 135: 68-78, 2019.

50. Eum WS, Shin MJ, Lee CH, Yeo HJ, Yeo EJ, Choi YJ, Kwon HJ, Kim DS, Kwon OS, Lee KW, et al: Neuroprotective effects of Tat-ATOX1 protein against $\mathrm{MPP}^{+}$-induced SH-SY5Y cell deaths and in MPTP-induced mouse model of Parkinson's disease. Biochimie 156: 158-168, 2019.

51. Takeuchi $\mathrm{O}$ and Akira S: Pattern recognition receptors and inflammation. Cell 140: 805-820, 2010.

52. Kim SM, Ha JS, Han AR, Cho SW and Yang SJ: Effects of $\alpha$-lipoic acid on LPS-induced neuroinflammation and NLRP3 inflammasome activation through the regulation of $\mathrm{BV}-2$ microglial cells activation. BMB Rep 52: 613-618, 2019.

53. Nishio K, Horie M, Akazawa Y, Shichiri M, Iwahashi H Hagihara Y, Yoshida Y and Niki E: Attenuation of lipopolysaccharide (LPS)-induced cytotoxicity by tocopherols and tocotrienols. Redox Biol 1: 97-103, 2013.

54. Wang M, Zhu K, Zhang L, Li L and Zhao J: Thioredoxin 1 protects astrocytes from oxidative stress by maintaining peroxiredoxin activity. Mol Med Rep 13: 2864-2870, 2016.

55. Stosic-Grujicic S, Stojanovic I, Maksimovic-Ivanic D, Momcilovic M, Popadic D, Harhaji L, Miljkovic D, Metz C, Mangano K, Papaccio G, et al: Macrophage migration inhibitory factor (MIF) is necessary for progression of autoimmune diabetes mellitus. J Cell Physiol 215: 665-675, 2008

56. Yamamoto M, Yamato E, Toyoda S, Tashiro F, Ikegami H, Yodoi J and Miyazaki J: Transgenic expression of antioxidant protein thioredoxin in pancreatic beta cells prevents progression of type 2 diabetes mellitus. Antioxid Redox Signal 10: 43-49, 2008

57. Sharif O, Bolshakov VN, Raines S, Newham P and Perkins ND Transcriptional profiling of the LPS induced NF-kappaB response in macrophages. BMC Immunol 8: 1, 2007.

58. Gilmore TD: Introduction to NF-kappaB: Players, pathways, perspectives. Oncogene 25: 6680-6684, 2006.

59. Saccani S, Pantano S and Natoli G: p38-Dependent marking of inflammatory genes for increased NF-kappa B recruitment. Nat Immunol 3: 69-75, 2002.
60. Zhang W and Liu HT: MAPK signal pathways in the regulation of cell proliferation in mammalian cells. Cell Res 12: 9-18, 2002.

61. Liu HT, Du YG, He JL, Chen WJ, Li WM, Yang Z, Wang YX and Yu C: Tetramethylpyrazine inhibits production of nitric oxide and inducible nitric oxide synthase in lipopolysaccharide-induced N9 microglial cells through blockade of MAPK and PI3K/Akt signaling pathways, and suppression of intracellular reactive oxygen species. J Ethnopharmacol 129: 335-343, 2010

62. Bald T, Landsberg J, Jansen P, Gaffal E and Tüting T: Phorbol ester-induced neutrophilic inflammatory responses selectively promote metastatic spread of melanoma in a TLR4-dependent manner. OncoImmunology 5: e1078964, 2015.

63. Kuo DH, Lai YS, Lo CY, Cheng AC, Wu H and Pan MH Inhibitory effect of magnolol on TPA-induced skin inflammation and tumor promotion in mice. J Agric Food Chem 58: 5777-5783, 2010.

64. Kim MJ, Kim DW, Park JH, Kim SJ, Lee CH, Yong JI, Ryu EJ, Cho SB, Yeo HJ, Hyeon J, et al: PEP-1-SIRT2 inhibits inflammatory response and oxidative stress-induced cell death via expression of antioxidant enzymes in murine macrophages. Free Radic Biol Med 63: 432-445, 2013

65. Sun J, Zhao Y, Jin $\mathrm{H}$ and Hu J: Curcumin relieves TPA-induced Th1 inflammation in K14-VEGF transgenic mice. Int Immunopharmacol 25: 235-241, 2015.

66. Lee DY, Choo BK, Yoon T, Cheon MS, Lee HW, Lee AY and Kim HK: Anti-inflammatory effects of Asparagus cochinchinensis extract in acute and chronic cutaneous inflammation. J Ethnopharmacol 121: 28-34, 2009.

67. Murakawa M, Yamaoka K, Tanaka Y and Fukuda Y: Involvement of tumor necrosis factor (TNF)-alpha in phorbol ester 12-O-tetradecanoylphorbol-13-acetate (TPA)-induced skin edema in mice. Biochem Pharmacol 71: 1331-1336, 2006.

68. Song HY, Lee JA, Ju SM, Yoo KY, Won MH, Kwon HJ, Eum WS, Jang SH, Choi SY and Park J: Topical transduction of superoxide dismutase mediated by HIV-1 Tat protein transduction domain ameliorates 12-O-tetradecanoylphorbol-13-acetate (TPA)-induced inflammation in mice. Biochem Pharmacol 75: $1348-1357,2008$

69. Xian YF, Hu Z, Ip SP, Chen JN, Su ZR, Lai XP and Lin ZX: Comparison of the anti-inflammatory effects of Sinapis alba and Brassica juncea in mouse models of inflammation. Phytomedicine 50: 196-204, 2018.

70. Kundu JK, Shin YK and Surh YJ: Resveratrol modulates phorbol ester-induced pro-inflammatory signal transduction pathways in mouse skin in vivo: NF-kappaB and AP-1 as prime targets. Biochem Pharmacol 72: 1506-1515, 2006.

71. Xian YF, Mao QQ, Ip SP, Lin ZX and Che CT: Comparison on the anti-inflammatory effect of Cortex Phellodendri Chinensis and Cortex PhellodendriAmurensisin 12-O-tetradecanoyl-phorbol-13acetate-induced ear edema in mice. J Ethnopharmacol 137 1425-1430, 2011

72. He XY, Liu QC, Peng W, Huang YL and Wu CJ: Bioactivities and serum pharmacochemistry of $\mathrm{O} i$-Wei-Xiao-Yan-Tang.Pharm Biol 51: 629-634, 2013.

73. Chang SN, Khan I, Dey DK, Cho KH, Hwang BS, Bae KB, Kang SC and Park JG: Decursinol angelate ameliorates 12-O-tetradecanoyl phorbol-13-acetate (TPA)-induced NF- $\mathrm{B}$ activation on mice ears by inhibiting exaggerated inflammatory cell infiltration, oxidative stress and pro-inflammatory cytokine production. Food Chem Toxicol 132: 110699, 2019.

74. Xu XT, Mou XQ, Xi QM, Liu WT, Liu WF, Sheng ZJ, Zheng X, Zhang K, Du ZY, Zhao SQ, et al: Anti-inflammatory activity effect of 2-substituted-1,4,5,6-tetrahydrocyclopenta $[b]$ pyrrole on TPA-induced skin inflammation in mice. Bioorg Med Chem Lett 26: 5334-5339, 2016.

75. Wu JY, Chen YJ, Bai L, Liu YX, Fu XQ, Zhu PL, Li JK, Chou JY, Yin CL, Wang YP, et al: Chrysoeriol ameliorates TPA-induced acute skin inflammation in mice and inhibits NF- $\kappa$ B and STAT3 pathways. Phytomedicine 68: 153173, 2020. 